\title{
PENDIDIKAN AGAMA DAN KEWIRAUSAHAAN SANTRI: KAJIAN PESANTREN ROUDHOTUL KHUFFADZ SORONG PAPUA BARAT
}

\author{
Ismail Suardi Wekke \\ Jurusan Dakwah, STAIN Sorong, Papua Barat \\ E-mail: iswekke@gmail.com \\ Cholichul Hadi \\ Fakultas Psikologi Unair Airlangga Surabaya \\ E-mail: choli_exp@yahoo.com \\ Disajikan dalam Temu Ilmiah Nasional Psikologi \\ Fakultas Psikologi Universitas Airlangga Surabaya \\ 20 - 21 November 2012
}

\begin{abstract}
ABSTRAK
Institusi pesantren menjadi salah satu pilar dalam proses pendidikan, tidak saja dalam konteks agama Islam tetapi menjadi kekayaan bangsa. Sebagai sentral pembinaan dan pengembangan kemampuan umat Islam, maka pesantren juga menjadi dinamisator dalam berbagai aspek kehidupan. Untuk itu, maka penelitian ini berupaya mengkaji dari sudut pembinaan keterampilan kewirausahaan. Penelitian dilaksanakan di Pesantren Roudhotul Khuffadz, Kabupaten Sorong, Provinsi Papua Barat. Pesantren ini dipilih sebagai subyek penelitian melalui observasi bahwa institusi pendidikan sejenis dalam wilayah Sorong Raya tidak menjadikan aspek kewirausahaan sebagai faktor utama dalam proses pendidikan. Sementara Pesantren Roudhotul Khuffadz, kemudian menjadikan pembinaan kewirausahaan merupakan kebutuhan dan target dalam pengembangan pendidikan. Jenis kualitatif diterapkan pendekatan dalam pelaksanaan penelitian. Observasi dan wawancara mendalam digunakan sebagai teknik pengumpulan data. Panduan observasi dan panduan wawancara senantiasa digunakan sebagai instrumen pengumpulan data selama penelitian berlangsung. Penelitian ini menunjukkan bahwa sebagai lembaga pendidikan, maka model pesantren menjadi acuan utama. Tetapi dilakukan beberapa pengembangan untuk menyesuaikan dengan kondisi umat Islam dalam konteks Papua. Lembaga ini kemudian menunjukkan dalam proses pendidikan agama adanya proses yang berjalan secara bersamaan. Keterampilan untuk persiapan dalam menjalani kehidupan senantiasa diasah, namun demikian pembinaan watak, penguasaan ilmu agama, amalan ibadah sebagai bagian tidak terpisahkan dari agama itu sendiri merupakan komponen pendidikan yang dijalankan. Akhirnya, kekhasan gagasan dan praktik dalam lembaga pendidikan ini menunjukkan bahwa pesantren juga melahirkan ide dan konstruksi yang berdampak dalam pembinaan santri tidak semata-mata nilai ritual tetapi juga kelangsungan kehidupan dalam bentuk kehidupan duniawi.
\end{abstract}

Kata kunci: pesantren, kesehatan mental, pendidikan agama, keterampilan hidup, Islam.

\section{A. PENDAHULUAN}

Pendidikan pada hakikatnya merupakan suatu upaya mewariskan nilai, yang akan menjadi penolong dan penentu umat manusia dalam menjalani kehidupan, dan sekaligus 
untuk memperbaiki nasib dan peradaban umat manusia. ${ }^{1}$ Tanpa pendidikan, maka diyakini bahwa manusia sekarang tidak berbeda dengan generasi manusia masa lampau, dibandingkan dengan manusia sekarang, telah sangat berbeda dalam pandangan dan praktik baik kualitas kehidupan maupun proses pemberdayaannya. Secara ekstrim bahkan dapat dikatakan bahwa maju mundurnya atau baik buruknya peradaban suatu masyarakat, suatu bangsa, akan ditentukan oleh bagaimana pendidikan yang dijalani oleh masyarakat bangsa tersebut. ${ }^{2}$ Ini menjadi bukti bahwa pendidikan menjadi proses transformasi peradaban antar generasi.

Pada era abad ke-21 ini, pendekatan pendidikan Islam berlangsung melalui proses operasional menuju pada tujuan yang diinginkan, memerlukan model yang konsisten yang dapat mendukung nilai-nilai moral-spritual dan intelektual yang melandasinya. Sebagaimana yang pertama kali dibangun Nabi Muhammad SAW nilai-nilai tersebut dapat diaktualisasikan berdasarkan kebutuhan dan perkembangan manusia yang dipadukan dengan pengaruh lingkungan kultural yang ada. Sehingga dapat mencapai cita-cita dan tujuan untuk meningkatkan kualitas hidup manusia di segala aspek kehidupannya. Tetapi apa yang terjadi, kondisi pendidikan Islam pada era abad ke-21, mendapat sorotan yang sangat tajam dan kurang menggembirakan dan dinilai menyandang keterbelakangan. Itu semua bermuara pada kelemahan yang dialaminya. Kelemahan pendidikan Islam justru pada sektor utama, yaitu pada konsep, sistem, dan kurikulum³ . Dianggap mulai kurang relevan dengan kemajuan peradaban umat manusia dewasa ini atau tidak mampu menyertakan disiplin-disiplin ilmu lain yang relevan dengan kebutuhan masyarakat.

Kenyataan yang ada saat ini, memasukkan pendidikan Islam dalam klasifikasi yang belum dapat dikatakan telah berjalan dan memberikan hasil secara memuaskan. Hal ini mempunyai pengertian belum mampu menjawab arus perkembangan zaman yang sangat deras, seperti timbulnya aspirasi dan idealitas yang serba multi interes dan berdemensi nilai ganda dengan tuntutan hidup yang amat beragam, serta perkembangan teknologi yang amat pesat. ${ }^{4}$ Dengan demikian, pendidikan dipandang tidak mampu merespon perkembangan dan

\footnotetext{
${ }^{1}$ Tedi Priatna, Reaktualisasi Paradigma Pendidikan Islam: Ikhtiar Mewujudkan Pendidikan Bernilai Ilahiah dan Insaniah di Indonesia, (Bandung: Pustaka Bani Quraisy, 2004), hal. 101.

${ }^{2}$ Anwar Arifin, Format Baru Pengelolaan Pendidikan, (Jakarta: Pustaka Indonesia, 2006), hal. 115.

${ }^{3}$ Kurikulum bergonta ganti dari tahun ke tahun, sehingga tenaga pendidik hanya dibingunkan dengan perubahan tersebut. Lihat Muhaimin, Pengembangan Kurikulum Pendidikan Agama Islam: di Sekolah, Madrasah, dan Perguruan Tinggi, (Jakarta: PT RajaGrafindo Persada, 2005), hal. 10.

${ }^{4}$ Hifni Muchtar, Fakta dan Cita-Cita Sistem Pendidikan Islam di Indonesia, (Yogyakarta: UNUSIA No.12 Th.XIII. UII.1992), hal. 52.
} 
kebutuhan yang ada. Sehingga selalu berada di garis belakang dibandingkan dengan tuntutan kebutuhan dan perkembangan lingkungan. Kemudian pilihan untuk berada di lembaga pendidikan formal kadang digugat. Bahkan fenomena lembaga bimbingan belajar semakin berkembang seiring keinginan untuk mendapatkan hasil belajar yang instan. Tidak sebatas itu saja, gugatan berkembang dengan semakin banyaknya tempat pelatihan. Dimana seolah-olah lembaga pendidikan tidak mampu lagi mengelola pendidikan itu sendiri.

Melihat kenyataan ini, maka pendidikan Islam perlu mendapat perhatian yang serius dalam menuntut pemberdayaan yang harus disumbangkan, dengan usaha menata kembali keadaannya, terutama di Indonesia. Keharusan ini, tentu dengan melihat keterkaitan dan peranannya di dalam usaha pendidikan bangsa Indonesia yang mayoritas Muslim, sehingga perlu ada terobosan seperti perubahan model dan strategi pelaksanaannya dalam menghadapi perubahan zaman. Tetapi dalam beberapa daerah seperti Papua dan Papua Barat, justru umat Islam berada dalam posisi minoritas. Dengan demikian, kita tidak bisa melakukan justifikasi secara general, sebab perkembangan pendidikan Islam juga berlangsung di daerah-daerah minoritas. Selama ini tinjauan pendidikan lebih banyak berada di tempat Islam sebagai mayoritas.

Usaha penataan kembali akan memperoleh keuntungan majemuk, pertama, pendidikan Islam subsistem pendidikan nasional di Indonesia, akan dapat memperoleh dukungan dan pengalaman positif. Kedua, pendidikan Islam dapat memberikan sumbangan dan alternatif bagi pembenahan sistem pendidikan di Indonesia dengan kekurangan, masalah, dan kelemahannya. Ketiga, sistem pendidikan Islam yang dapat dirumuskan akan memiliki akar yang lebih kokoh dalam realitas kehidupan masyarakat. ${ }^{5}$ Dengan penataan ini, maka pesantren dalam bentuk madrasah akan lebih memberikan daya dukung bagi pengembangan sumber daya manusia.

Secara umum permasalahan pendidikan tersebut mungkin saja terjadi dimana-mana. Dalam skala wilayah Sorong, Papua Barat, dimana muslim menjadi minoritas, maka penting adanya satu penelitian yang mengungkapkan pembahasan bagaimana pendidikan Islam dalam perannya untuk memberdayakan masyarakat.

\section{B. PENDIDIKAN ISLAM DAN MASALAHNYA}

5 Suyata, Penataan Kembali Pendidikan Islam pada Era Kemajuan Ilmu dan Teknologi, (Yogyakarta: UNISIA, No. 12 th.XIII, UII, 1992), hal. 23. 
Pendidikan Islam bermakna usaha untuk mentransfer nilai-nilai budaya Islam kepada generasi mudanya, masih dihadapkan pada persoalan dikotomis dalam sistem pendidikannya. Pendidikan Islam bahkan diamati dan disimpulkan terkungkung dalam kemunduran, kekalahan, keterbelakangan, ketidakberdayaan, perpecahan, dan kemiskinan. ${ }^{6}$ Sebagaimana pula yang dialami oleh sebagian besar negara dan masyarakat Islam dibandingkan dengan mereka yang non Islam. Bahkan, pendidikan yang apabila diberi embel-embel Islam juga dianggap berkonotasi kemunduran dan keterbelakangan, meskipun sekarang secara berangsurangsur banyak di antara lembaga pendidikan Islam yang telah menunjukkan kemajuan. ${ }^{7}$

Pandangan ini sangat berpengaruh terhadap sistem pendidikan Islam, yang akhirnya dipandang selalu berada pada posisi deretan kedua dalam konstelasi sistem pendidikan di Indonesia, walaupun dalam undang-undang sistem pendidikan nasional menyebutkan pendidikan Islam merupakan sub-sistem pendidikan nasional. Tetapi predikat keterbelakangan dan kemunduran tetap melekat padanya, bahkan pendidikan Islam sering dinobat hanya untuk kepentingan orang-orang yang tidak mampu atau miskin. Pendidikan Islam lebih banyak diakses kalangan pedesaan dan kaum tidak berada. Dengan biaya yang tidak membebani peserta didik.

Dengan pandangan tersebut, maka pendidikan Islam di Indonesia dewasa ini memberi kesan yang tidak mengembirakan. Meskipun, kata Muchtar Buchori, tidak dipandang sebagai evidensi ${ }^{8}$ yang pada zaman dulu sempat ada pandangan yang dapat dikongklusifkan dalam penglihatannya ialah kenyataan, bahwa setiap kali ada murid-murid dari suatu lembaga pendidikan Islam yang turut serta dalam lembaga cerdas tangkas atau lomba cepat-tepat di TVRI, maka biasanya kelompok ini mendapatkan nilai terendah. Evidensi yang kedua ialah partisipasi siswa-siswi dari dunia pendidikan Islam dalam kegiatan nasional lomba karya ilmiah remaja masih sangat rendah. ${ }^{9}$ Hal ini merupakan suatu kenyataan yang selama ini dihadapi oleh lembaga pendidikan Islam di Indonesia. Namun dua ukuran tersebut tidak bisa menjadi parameter utama dalam memandang pendidikan Islam dalam menunjukkan

\footnotetext{
${ }^{6}$ Lihat Abdurrahman Mas'ud, Menggagas Format Pendidikan Nondikotomik: Humanisme Religius sebagai Paradigma Pendidikan Islam, (Yogyakarta: Gama Media, 2002), hal. 4.

7 Suroyo, Berbagai Persoalan Pendidikan Nasional dan Pendidikan Islam di Indonesia, Jurnal Ilmu Pendidikan Islam, Problem dan Prospeknya, (Yogyakarta: Volume 1, Fak. Tarbiyah IAIN Sunan Kalijaga, 1991), hal. 77.

${ }^{8}$ Evidensi adalah kenyataan yang tampak, penampakan yang jelas, alat bukti, tanda penyaksian, dan keterangan. Lihat Pius A. Partanto, dkk, Kamus Ilmiah Populer, (Surabaya: Arkola, 1994), hal. 164.

9 Pius A. Partanto, dkk, Kamus Ilmiah Populer, hal. 77.
} 
keterbelakangan. Sebab masih banyak factor lain yang justru sebaliknya sebagai tanda bahwa geliat dan dinamika pendidikan Islam justru mengalami kemajuan.

Dalam konfigurasi sistem pendidikan nasional, pendidikan Islam di Indonesia merupakan salah satu variasi dari konfigurasi sistem pendidikan nasional, tetapi kenyataannya pendidikan Islam tidak memiliki kesempatan yang luas untuk bersaing dalam membangun umat yang besar ini. Apabila dirasakan, memang terasa janggal bahwa dalam komunitas masyarakat Muslim, pendidikan Islam tidak mendapat kesempatan yang luas untuk bersaing dalam membangun umat yang besar ini. Apalagi perhatian pemerintah yang dicurahkan pada pendidikan Islam sangatlah kecil porsinya, padahal masyarakat Indonesia selalu diharapkan agar tetap berada dalam lingkaran masyarakat yang sosialistis religius. ${ }^{10}$ Tetapi justru pendidikan Islam lebih banyak menunjukkan pola swadaya. Sehingga walaupun tanpa perhatian dari stakeholder, pendidikan Islam tetap dapat berkembang dengan baik. Bahkan sama sekali bukan menjadi beban, tetapi sebaliknya menjadi kebanggaan bangsa di tengah minimnya perhatian pengambil kebijakan pendidikan.

Realitas pendidikan Islam pada umumnya memang diakui mengalami kemunduran dan keterbelakangan, walaupun akhir-kahir ini secara berangsur-angsur mulai terasa kemajuannya. Ini terbukti dengan berdirinya lembaga-lembaga pendidikan Islam dan beberapa model pendidikan yang diterapkan. Tetapi tantangan yang dihadapi tetap sangat kompleks, sehingga menuntut inovasi pendidikan Islam itu sendiri dan ini tentu merupakan pekerjaan yang besar dan sulit. Sebagaimana A. Mukti Ali, membeberkan tentang kelemahan-kelemahan pendidikan Islam dewasa ini disebabkan oleh beberapa faktor yaitu kelemahan dalam penguasaan sistem dan metode, bahasa sebagai alat untuk memperkaya persepsi, ketajaman interpretasi, kelemahan dalam kelembagaan, ilmu, dan teknologi. ${ }^{11}$ Maka dari itu, pendidikan Islam didesak untuk melakukan inovasi tidak hanya yang bersangkutan dengan kurikulum dan perangkat manajemen, tetapi juga strategi dan taktik operasionalnya. Strategi taktik itu, bahkan sampai menuntut perombakan model-model sampai institusi-institusinya sehingga lebih efektif, dan efisien, dalam arti pedegogis, sosiologis, dan kultural dalam menunjukkan perannya.

${ }^{10}$ Muslih Usa, Pendidikan Islam di Indonesia: Antara Cita dan Fakta (Suatu Pengantar), (Yogyakarta: Tiara Wacana, 1991), hal. 11.

11 M. Arifin, Kapita Selekta Pendidikan, (Jakarta: Bina Aksara, 1991), hal. 3. 


\section{PENATAAN PENDIDIKAN ISLAM DI INDONESIA}

Krisis pendidikan di Indonesia secara umum diungkapkan oleh H.A. Tilaar bahwa diidentifikasi dalam empat krisis pokok yaitu menyangkut masalah kualitas, relevansi, elitisme, dan manajemen.12 Berbagai indikator kuantitatif dikemukakan berkenaan dengan keempat masalah di atas, antara lain analisis komparatif yang membandingkan situasi pendidikan antara negara di kawasan Asia. Memang disadari bahwa keempat masalah tersebut merupakan masalah besar, mendasar, dan multidimensional, sehingga sulit dicari ujung pangkal pemecahannya.

Krisis ini terjadi pada pendidikan secara umum, termasuk pendidikan Islam yang dinilai justru lebih besar problematikanya. Karena itu, menurut, A. Syafii Maarif bahwa situasi pendidikan Islam di Indonesia sampai abad ini tidak banyak berbeda dengan perhitungan kasar di atas. Sistem pondok pesantren yang berkembang di nusantara dengan segala kelebihannya, juga tidak disiapkan untuk membangun peradaban. ${ }^{13}$ Melihat persoalan yang dihadapi, maka penataan model pendidikan Islam di Indonesia adalah suatu yang lebih terelakkan. Strategi pengembangan pendidikan Islam hendaknya dipilih dari kegiatan pendidikan yang paling mendesak, berposisi sentral yang akan menjadi modal dasar untuk usaha pengembangan selanjutnya. Seperti kita ketahui, bahwa lembaga-lembaga pendidikan seperti keluarga, sekolah, madrasah, masjid, pondok pesantren, dan pendidikan luar sekolah lainnya tetap dipertahankan keberadaannya.

Untuk penataan kembali pendidikan Islam, tampaknya perlu kita menoleh sejarah perkembangan Islam pada abad ke-19, di mana dunia Islam mulai mengenal sistem madrasah yang ternyata telah menimbulkan perubahan radikal dalam sistem pendidikan Islam. Sistem madrasah yang diorganisasikan secara formal, secara berangsur-angsur mengalahkan pusatpusat pendidikan yang lebih liberal. Inti kurikulum madrasah terpusat pada al-Qur'an, alHadits, fiqih, dan bahasa Arab. Bentuk-bentuk pengetahuan yang tidak diperoleh di madrasah seperti filsafat, kimia, astronomi, dan matematika dipelajari secara individual dan dalam lingkungan yang terbatas. Bahkan disiplin-disiplin ini ditempatkan di bawah payung disiplin lain seperti ilmu perobatan. ${ }^{14}$ Dalam beberapa model, pendidikan Islam mulai mengajarkan

12 Lihat H.A. Tilaar, Sistem Pendidikan Nasional yang Kondusif bagi Pembangunan Masyarakat Industri Modern Berdasarkan Pancasila, Makalah Utama Kongres Ilmu Pengetahuan Nasional V.

${ }^{13}$ Muslih Usa, Pendidikan Islam di Indonesia, hal. 37.

${ }^{14}$ George Makdisi, Terjemahan A. Syafii Maarif, 1996, h. 3. 
ilmu yang juga diajarkan di sekolah umum. Bahkan filsafat dan ilmu logika termasuk dalam kurikulum pengajaran. Keberadaan lembaga pendidikan Islam yang disebutkan di atas cukup variatif, sekalipun mungkin peran dan fungsinya masih dipertanyakan dalam konfigurasi pendidikan nasional. Dengan hal tersebut fungsi pendidikan Islam dari lembaga atau tempat pendidikan tersebut, perlu dirumuskan secara lebih spesifik, efektif, dan bermutu tinggi, agar dapat menjawab tantangan yang dihadapi.

Kalau kita telaah literatur dalam pendidikan Islam, maka dapat diketahui bahwa fungsi dan tujuan pendidikan Islam diletakkan jauh lebih berat tanggungjawabnya bila dibandingkan fungsi pendidikan pada umumnya. Sebab, fungsi dan tujuan pendidikan Islam harus memberdayakan atau berusaha menolong manusia untuk mencapai kebahagiaan dunia dan akhirat. Oleh karenanya, maka konsep dasarnya bertujuan untuk melahirkan manusia-manusia yang bermutu atau sering disebut di al-Qur'an dengan (insan kamil). Dengan tugas utama untuk mengelola dan memanfaatkan bumi ini dengan ilmu pengetahuan untuk kebahagiaannya yang dilandasi pada konsep spritual untuk mencapai kebahagiaan akhiratnya. Sebagaimana dikatakan para ahli, bahwa pendidikan Islam berupaya untuk mengembangkan semua aspek dalam kehidupan manusia yang meliputi spritual, intelektual, imajinasi, keilmuan baik individu maupun kelompok, dan memberi dorongan bagi dinamika aspek-aspek di atas menuju kebaikan dan pencapaian kesempurnaan hidup baik dalam hubungannya dengan alKhaliq, sesama manusia, maupun dengan alam. ${ }^{15}$ Akan tetapi pada tataran operasional, rumusan-rumusan idel yang dikemukakan di atas belum terjawab. Sedangkan lembaga pendidikan Islam cukup variatif dalam berusaha melendingkan konsep-konsep tersebut, namun belum berdaya dan posisi pendidikan Islam sendiri masih terlihat begitu lemah. Melihat kenyataan ini, maka inovasi atau penataan fungsi pendidikan Islam terutama pada sistem pendidikan persekolahan, harus diupayakan secara terus menerus, berkesinambungan, dan berkelanjutan, sehingga nanti usahanya dapat menjamah pada perluasan dan pengembangan sistem pendidikan Islam luar sekolah.

Di samping inovasi pada sisi kelembagaan, faktor tenaga pendidikan juga harus ditingkatkan aspek etos kerja dan profesionalismenya, perbaikan materi (kurikulum) yang metodologi masih berorientasi pada sistem tradisional, dan perbaikan manajemen pendidikan itu sendiri. Untuk itu, maka usaha untuk melakukan inovasi tidak hanya sekedar tambal sulam,

${ }^{15}$ M. Arifin, Kapita Selekta Pendidikan, hal. 15. 
tetapi harus secara mendasar dan menyeluruh, mulai dari fungsi dan tujuan, metode, materi (kurikulum), lembaga pendidikan, dan pengelolaannya. Penataan pada fungsi pendidikan Islam, tentu dengan memperhatikan pola dunia kerja. Sebab, dunia kerja mempunyai andil dan rentang waktu yang cukup besar dalam jangka kehidupan pribadi dan kolektif. Pembenahan pendidikan dapat memilih sasaran model pendidikan bagi kelompok masyarakat yang kurang beruntung di kalangan orang dewasa. Perbaikan wawasan, sikap, pengetahuan, keterampilan, diharapkan akan memperbaiki kehidupan sosio-kultural dan ekonomi mereka. Pilihan sasaran berikutnya dapat ditujukan bagi pendidikan terhadap anak. Konsumsi pendidikan dan hiburan untuk kelompok ini, belum tampak sangat berkembang, kecuali usaha-usaha yang secara naluriah telah diwariskan dari waktu ke waktu. ${ }^{16}$

Perbaikan fungsi pendidikan Islam pada tahap lanjut, harus dilakukan menjadi satu kesatuan dengan lembaga pendidikan Islam lainnya yang terkait erat sekali, seperti masjid dengan kesatuan jamaahnya, madrasah/sekolah, keluarga Muslim, masyarakat Muslim di suatu kesatuan territorial, dan lain sebagainya. Dengan konteks tersebut, maka sekurangkurangnya ada empat jenis lembaga pendidikan Islam yang dapat mengambil peran ini, yaitu pendidikan pondok pesantren, masjid, madrasah, pendidikan yang bernafaskan Islam.

Dengan hal tersebut, Soeroyo menempatkan jenis lembaga pendidikan yang disebut pertama dan kedua, sebagai lembaga pendidikan Islam yang dapat mengembangkan atau memperluas sistem pendidikan non formalnya pada pelayanan pendidikan yang meliputi berbagai jenis bidang misalnya, seperti bidang pertanian, peternakan, elektronik, kesehatan, kesenian, kepramukaan, kemajuan IPTEK, perbagai keterampilan, kesenian, dan lain sebagainya. Sedangkan pondok pesantren, seharusnya memperluas pelayanan pendidikan kepada masyarakat secara wajar dan sistematis, sehingga apa yang disajikan kepada masyarakat, akan tetap terasa bermuara pada pandangan serta sikap islami, dan terasa manfaatnya bagi kehidupan sehari-hari. Begitu juga mengenai aktivitas masjidnya, pondok pesantren dan masjid perlu menggalang kerjasama dengan para ulama dan para cendikiawan Muslim yang tergabung dalam perguruan tinggi yang ada di sekitarnya. Adapun peranan jenis yang ketiga dan keempat, yaitu pendidikan madrasah dan pendidikan umum, adalah dalam menemukan pembaruan dalam sistem pendidikan formal yang meliputi metode pengajaran 
baik agama maupun umum yang efektif. Inovasi di bidang kurikulum, alat-alat pengajaran, lingkungan yang mendidik, guru ${ }^{17}$ yang kreatif dan penuh dedikasi dan sebagainya.

Sebenarnya sudah ada lembaga pendidikan Islam yang menjadi sekolah favorit dan banyak diminati, secara umum aspirasi masyarakat terhadap sekolah-sekolah Islam masih rendah. Dalam banyak hal, ini kembali berkolerasi dengan ketidakberdayaan lembaga-lembaga pendidikan Islam dalam memenuhi logika persaingan dalam memenuhi tuntutan perkembangan zaman.18 Munculnya Madrasah Aliyah Program Khusus (MAPK) kemudian bermetamorfosis menjadi Madrasah Aliyah Khusus (MAK) yang dapat dikategorikan sebagai fenomena sekolah unggulan Islam, kemudian betul-betul merupakan aset pendidikan Islam yang turut berpartisipasi dalam dunia pendidikan dengan sekolah-sekolah umum lainnya. Tetapi juga belum mendapatkan posisi yang menguntungkan dalam konfigurasi pendidikan nasional. Seiring dengan kebijakan pendidikan di lingkungan Kementerian Agama, MAK akhirnya dilebur ke dalam Madrasah Aliyah reguler.

Pada sisi lain, muncul pula pendidikan luar sekolah bagi anak-anak Muslim seperti TPA (Taman Pendidikan al-Qur'an) sebagai kekuatan pendidikan Islam baru yang muncul dengan metode dan teknik baru yang dapat menghasilkan output yang mampu membaca al-Qur'an dalam waktu yang relatif singkat. ${ }^{19}$ Dapat kita saksikan produk TPA bangga diwisuda oleh seorang Menteri bahkan tidak tanggung-tanggung oleh Presiden. Akan tetapi sampai saat ini belum terpikirkan tindak lanjut dari usaha pendidikan ini, karena setelah wisuda selesai, maka selesailah usaha pendidikan tersebut, bahkan juga terjadi di tataran pendidikan Islam perguruan tinggi.

Kepincangan-kepincangan pendidikan Islam yang dikemukakan di atas, mestinya tidak kita bicarakan berlarut-larut, akan tetapi kita harus berusaha untuk mengoreksi secara cermat program-program pendidikan yang sedang dijalankan, sehingga pemisah antara pendidikan Islam dengan pendidikan umum dalam konfigurasi pendidikan nasional dapat diatasi. Tujuan dan fungsi pendidikan Islam, metode, materi (kurikulum) harus dikoreksi dan direvisi secara

17 Selain hal tersebut guru harus termotivasi untuk banyak membaca, berlatih berkarya, serta menjadi figur inspirator dan motivator bagi anak didik dan masyarakat. Lihat Jamal Ma'ruf Asmani, Manajemen Pengelolaan dan Kepemimpinan Pendidikan Profesional: Panduan Quality Control bagi Para Pelaku Lembaga Pendidikan, (Yogyakarta: Diva Press, 2009), hal. 58.

18 Hery Noer Aly dan Munzier S., Watak Pendidikan Islam, (Jakarta Utara: Friska Agung Insani, 2003), hal. 234.

${ }_{19}$ M. Suyudi, Pendidikan dalam Perspektif al-Qur'an Integrasi Epistemologi Bayani, Burhani, dan Irfani, (Yogyakarta: Mikraj, 2005), hal. 15. 
berani dan membenahi keorganisasiannya (kelembagaan), sehingga akan menarik minat peserta didik tanpa mengurangi prinsip-prinsip ajaran dari sumber pokok Islam. ${ }^{20}$ Dengan demikian, pendidikan Islam akan kembali solid dalam memberdayakan umat Islam di Indonesia yang sedang menuju pada masyarakat industrial dengan berbagai tantangan etos kerja, profesionalisme, dan moralitas. Bagaimanapun juga kedekatan dengan kebenaran, dan alKhaliq yang dimiliki oleh ruh dan nafas pendidikan Islam, keunggulannya harus tetap diraih dengan usaha. Atau kita akan menerima kemarahan Allah SWT karena melalaikan pendidikan Islam, yang dinilai oleh para ahli sebagai satu-satunya lembaga pendidikan yang dapat menghidupkan keseimbangan perkembangan dalam setiap diri manusia. Perkembangan sosial sarat dengan banyak hal diantaranya perubahan masyarakat, termasuk di dalamnya proses industrialisasi.

\section{PENDIDIKAN ISLAM DAN PEMBERDAYAAN: TEORI DAN PRAKTEK}

Pendidikan Islam, dalam bentuk madrasah telah memberikan peran yang dinamis dalam pendidikan nasional Indonesia. Bahkan sejak masih zaman penjajahan, pesantren telah memberikan hasil nyata dengan turut melaksanakan usaha-usaha dalam pembentukan masyarakat yang melek huruf (literacy) dan melek budaya (cultural literacy) ${ }^{21}$. Ini menjadi fakta sejarah, bahwa dalam perkembangan pesantren, pendidikan hanya menjadi salah satu usaha pengembangan pesantren. Dengan demikian sangat perlu juga untuk kembali menelusuri bagaimana peran pesantren dalam konteks pemberdayaan masyarakat.

Pesantren bersentuhan dengan modernisasi, ditandai dengan mulainya menggunakan metode dan strategi modern untuk pembelajaran. Tetapi tidak bermakna westernisasi (pembaratan) tetapi merupakan jawaban atas stigma yang diberikan kepada label tradisional. Ketika salah satu pesantren terkemuka, Pesantren Gontor, saat mulai digagas sistem pendidikan saat itu masih dalam bentuk tradisional. Pengajaran dan pembelajaran masih berbasis pada sorogan, bandongan, halaqah dan hafalan untuk melakukan transfer keilmuan ${ }^{22}$. Dalam proses pembelajaran yang dijalankan di Gontor mulai terinspirasi metode yang

\footnotetext{
20 A. Malik Fadjar, Holistika Pemikiran Pendidikan, (Jakarta: PT RajaGrafindo Persada, 2005), hal. 121.

${ }_{21}$ Mujamil Qomar, Pesantren; dari Transformasi Metodologi Menuju Demokratisasi Institusi, (Jakarta: Erlangga, $\mathrm{tt}$ ), hal. xiii.

${ }_{22}$ Mastuhu, Dinamika Pendidikan Pesantren: Suatu Kajian tentang Unsur dan Nilai Sistem Pendidikan Pesantren, Seri INIS XX, (Jakarta: INIS, 1994), hlm. 61.
} 
dilakukan sistem pendidikan kolonial Belanda ${ }^{23}$. Saat itu ada dua corak pendidikan, dimana pendidikan pesantren sebagai satu-satunya pendidikan formal yang sudah eksis bahkan sebelum kedatangan pemerintahan kolonial. Kemudian seiring dengan kedatangan Belanda, memperkenalkan sekolah modern yang menganut sistem persekolahan yang berkembang di Eropa24. Di samping itu, kata modern selain bermakna sistem pendidikan yang tidak efektif juga dimaknai sebagai kejumudan berfikir. Untuk itu, dengan melekatnya kata modern dalam sistem pendidikan Gontor diartikulasi sebagai kebebasan berpikir, manajemen efektif dan efisien, dan pengenalan santri terhadap modernitas ${ }^{25}$. Dengan demikian, pesantren berupaya untuk tidak mengarahkan untuk taklid terhadap madzhab tertentu sehingga mendorong kepada kebebasan berpikir. Sementara manajemen efektif dan efisien diimplemetasikan dalam bentuk pengelolaan keuangan dan adminsitrasi pesantren yang transparan dan akuntabel. Termasuk pula kepemimpinan yang tidak terfokus kepada individu dan keluarga kiyai tetapi lebih kepada sebuah Badan Waqaf. Kepemilikan kiyai dan keluarga sepenuhnya diserahkan kepada lembaga yang berbentuk badan waqaf.

Dalam pandangan Greg Barton²6, pendidikan islam seperti Gontor merupakan lembaga pendidikan yang berhasil memadukan antara keperluan belajar ilmu Islam klasik dengan gaya kekinian. Penggunaan sistem pengajaran dalam mata pelajaran keislaman memungkinkan peserta didik tidak tersandera pada masa lalu kemudian ketinggalan untuk berkompetisi di masa sekarang. Bahkan dengan perpaduan khazanah ilmu Islam warisan masa lalu yang disandingkan dengan metodologi pengajaran di zaman sekarang, pada gilirannya menghasilkan institusi pendidikan yang komprehensif dan kemudian menjadi solusi bagi kepentingan pendidikan umat Islam. Pada zaman pendirian tersebut, lembaga pendidikan Islam di saat itu sebatas mengajarkan khazanah Islam klasik yang ditransfer dengan menggunakan metode tradisional. Walaupun demikian, sudah ada pesantren yang sudah berani melangkah dengan mengdopsi gaya pendidikan yang dilaksanakan di sekolah-sekolah

${ }^{23}$ Dalam paparan Abudien Nata bahwa pendidikan Islam di Indonesia mulai mengadopsi metode pembelajaran yang diterapkan pemerintahan kolonial Belanda sejak tahun 1906. Abudien Nata, Tokohtokoh Pembaharuan Pendidikan Islam di Indonesia, (Jakarta: PT Raja Grafindo Persada, 2005) hal. 12.

${ }^{24}$ Hasbullah, Kapita Selekta Pendidikan Islam, (Jakarta: PT. Grafindo Perkasa, 1996), hal. 14.

25 Panitia Penyusunan Riwayat Hidup dan Perjuangan K.H. Imam Zarkasyi, Biografi K.H. Imam Zarkasyi: Dari Gontor Merintis Pondok Modern, (Ponorogo: Gontor Press, 1996).

${ }_{26}$ Greg Barton, Gagasan Islam Liberal di Indonesia, Pemikiran Neo-Modernisme Nurcholish Madjid, Djohan Efendi, Ahmad Wahib, dan Abdurrahman Wahid, 1968-1980, terj. Nanang Tahqiq, (Jakarta: Paramadina, 1999), hal. 75-77. 
kolonial Belanda. Sehingga materi pendidikan tetap merujuk kepada kekayaan tradisi Islam dengan memberikan penguatan pada ilmu alat untuk menguasai kitab-kitab tetapi metode penyampaian sudah menggunakan strategi modern.

Jika kemudian melihat perjalanan sejarah, maka sesungguhnya pesantren telah berada dalam domain pendidikan sebagai salah satu ranah pengabdian. Makalah ini kembali mencoba untuk memberikan ulasan bagaimana peran yang dimainkan pesantren yang berhubungan dengan pemberdayaan masyarakat. Data dalam makalah ini didapatkan dari Pesantren Roudhatul Khuffadz, Sorong, Papua Barat.

\section{a. Pendidikan Islam di Daerah Minoritas}

Kajian pendidikan Islam sudah menjadi perhatian yang khusus para sarjana. Walau demikian, perhatian tersebut masih sebatas pada pola pendidikan Islam di daerah mayoritas dan pendidikan Islam dengan posisi sebagai mainstream pendidikan. Akan tetapi kajian dan publikasi mengenai pendidikan di daerah minoritas muslim masih terbatas. Untuk itu, makalah ini berupaya untuk mengungkapkan pembahasan mengenai pendidikan Islam di daerah minoritas. Keberadaan pendidikan Islam di daerah seperti di Sorong baik dalam wilayah kota maupun kabupaten, maka tidak saja mengukuhkan akan identitas keberagamaan tetapi juga sebagai bukti pengakuan akan keberagamaan manusia Indonesia. Pada porsi identitas ini sebagaimana ditegaskan Rose \& Rose $^{27}$ bahwa keberadaan minoritas mendorong mereka untuk mempertahankan identitas dari mayoritas, namun dalam konteks keberagaman Indonesia, ketika muslim di wilayah lain justru menikmati kebebasan beragama karena mayoritas tetapi muslim Sorong Raya justru dalam posisi menikmati kebebasan beragama karena status sebagai minoritas. Bukan karena agama yang mereka peluk tetapi keberanian mereka untuk berbeda dengan saudara Papua yang lain.

Sementara itu, segregasi yang terjadi di beberapa belahan dunia lain dimana Islam menjadi minoritas justru tidak terjadi dalam keseharian masyarakat Papua di Sorong Raya. Jika kita membandingkan dengan Thailand ${ }^{28}$ dimana etnis Melayu tidak mendapatkan tempat untuk terbuka dan memperlihatkan identitas tetapi pada kehidupan masyarakat Sorong, segregasi ini tidak ditemukan. Mungkin ini karena faktor minoritas secara lokal tetapi mayoritas secara kebangsaan. Walaupun kadang etnisitas Papua dianggap sebagai sebagai

${ }^{27}$ M. Arnold Rose dan B. Caroline Rose, Minority Problems, (New York: Harper and Row, 1972).

${ }^{28}$ W. K. Che Man, Muslim Separatism, (Oxford: Oxford University Press, 1990). 
pembeda bagi masyarakat Indonesia secara umum juga kekhasan yang dimiliki masyarakat Papua, tetapi sejak 2001 mulai melemah ${ }^{29}$. Di masa Orde Baru, dalam pandangan Aspinnal dan Berger $^{30}$ bahwa wujud sentimen primordial mulai terbentuk sehingga berimplikasi kepada adanya pilihan untuk merdeka yang merupakan tujuan yang tidak dapat ditawar.

Pesantren dalam kondisi kota Sorong, memberikan kontribusi signifikan sebagai salah satu lembaga yang mendukung adanya keharmonisan dalam interaksi sosial antar pemeluk agama dan etnis ${ }^{31}$. Penelitian Mujahidah menunjukkan keberadaan lembaga-lembaga pendidikan Islam menjadi katalisator sekaligus memberikan penguatan kapasitas bagi peserta didik untuk tetap mempertahankan keharmonisan yang ada. Dengan pola interaksi yang tidak saja dalam hubungan sosial tetapi juga saling membantu dalam aktivitas keagamaan. Konteks kota Sorong, fenomena kerjasama bukan sesuatu yang asing. Bahkan dalam satu lingkungan terkadang hidup masayarakat yang berbeda etnis, agama dan status sosial yang lain. Sehingga dengan interaksi yang ada, mungkin saja ada batasan-batasan yang mebedakan antar kelompok dalam hubungan sosial 32 .

Dengan pola interaksi seperti yang dikemukakan di atas, maka menjadi penting adanya kesadaran identitas. Identifikasi-identifikasi menjadi penting ketika individu dalam kaitanya dengan situasi masyarakat ${ }^{33}$. Individu tidak lagi dipandang semata-mata sebagai pribadi tetapi dipandang juga sebagai anggota masyarakat ${ }^{34}$. Dengan demikian, posisi pesantren sebagai lembaga pendidikan menjadi penting untuk memberikan sosialisasi secara formal bagaimana pola interaksi dan perilaku dalam bermasyarakat tanpa meninggalkan identitas keberagamaan dalam masyarakat yang beragam. Walaupun juga potret pendidikan Papua yang masih jauh

29 Syafuan Rozi, Nasionalisme, Demokratisasi, dan Sentimen Primordialisme di Indonesia: Problematika Identitas Keetnisan versus Keindonesiaan pada Studi kasus Aceh, Papua, Bali, dan Riau, Jurnal Penelitian Politik, 6 (1), 2009, hal. 75-84.

${ }^{30}$ E. Aspinall dan M. T. Berger, The Break Up of Indonesia? Nationalism after Decolonisation and the Limits of the Nation-State in Post-Cold War Southeast Asia, Third World Quarterly, 22 (6), 2001, hal. 139-169.

31 Mujahidah, Analisis Terhadap Interaksi Sosial Antar Pemeluk Agama dan Etnis di Kota Sorong, (Sorong: Pustaka Rafana, 2010), hal. 61.

32 Suryosumarto Budisantoso, Ketahanan Nasional Indonesia, Penangkal Disintegrasi Bangsa dan Negara, (Jakarta: Pustaka Sinar Harapan, 2001).

${ }_{33}$ Muhammad Sofyan, Agama dan kekerasan dalam Bingkai Reformasi, (Yogyakarta: Penerbit Media Pressindo, 1999).

${ }^{34}$ Suwito, Sosiolinguistik: Teori dan Problema, (Surakarta: Henary Offset, 1982), hal. 2. 
dari harapan ${ }^{35}$ tetapi keberadaan pesantren Roudatul Khuffadz akan menjadi pionir dan pijar di tengah masyarakat. Pelayanan pendidikan yang dijalankan lebih dekat dengan muslim Papua, didirikan, dijalankan dan untuk muslim Papua. Tidak hanya memberikan edukasi dalam bentuk pendidikan formal tetapi lebih dari itu menjangkau bagaimana menguatkan keterampilan sesama muslim. Di tengah keterbatasan untuk akses pendidikan dan praduga, maka kewujudan pesantren ini menempati posisi yang khas.

Jika melihat perjalanan sejarah Eropa, identitas etnis, agama, ras, warna kulit jauh terlampaui ketika diperhadapkan pada identitas Negara bangsa (nation-state) ${ }^{36}$. Nasib minoritas belum tentu bermakna terpinggirkan dan mendapat akses yang serba terbatas dalam politik. Karena dalam pandangan Azyumardi Azra, proses minoritas tidak tunggal dan seragam ${ }^{37}$. Dalam beberapa wilayah bahkan minoritas muslim mengalami proses kebangsaan yang dinamis.

\section{b. Pemberdayaan Masyarakat dan Pesantren}

Salah satu penyebab kemiskinan dinyatakan Sayogyo bahwa adanya kemiskinan struktural karena polarisasi lahan pertanian. ${ }^{38}$ Untuk itu, maka dengan memberdayakan pengelolaan pertanian akan mengurangi potensi kemiskinan. Pemilihan pertanian sebagai upaya untuk pengelolaan pangan akan menjadi indikasi bahwa salah satu hal yang terpenting dalam bagian kemiskinan itu sendiri adalah mengatasi kebutuhan makan. Dengan demikian, akan memberikan kesempatan masyarakat untuk mengatasi masalah mulai dari keperluan individu. Namun demikian tidak sebatas pada pengelolaan lahan saja. Dibutuhkan juga adanya keterampilan dalam pemahaman tekhnologi. Dengan transfer teknologi ke pedesaaan kemudian diharapkan adanya peningkatan kesejahteraan. ${ }^{39}$ Untuk itu salah satu program pemberdayaan yang sangat aktual dengan melakukan pemberdayaan yang dilaksanakan di desa. Program pemberdayaan desa sebagai kelompok utama komunitas merupakan salah satu

35 Ahmad Arif dan Luki Aulia, Frederick Sitaung, Guru Sejati di Papua, Kompas, Sabtu, 1 September 2007.

36 Maxime Rodinson, The Notion of Minority in Islam, dalam Gerard Chaliand (ed.), Minority Peoples in the Age of Nation-States, (London: Pluto Press, 1989), hal. 23-25.

37 Azyumardi Azra, Wacana Tentang Minoritas Muslim, Kata Pengantar dalam M. Ali Kettani, Minoritas Muslim di Dunia Dewasa Ini, (Jakarta: Rajawali Pers, 2005), hal. xxv.

38 Sajogyo, Memahami dan Menanggulangi Kemiskinan di Indonesia, (Jakarta: Gramedia Widiasarana Indonesia, 1996), hal. 53.

39 Ginandjar Kartasasmita, Pembangunan Untuk Rakyat: Memadukan Pertumbuhan dan Pemerataan, (Jakarta: Center for Information and Development Studies, CIDES, 1996), hal. 81. 
sarana dalam pemberdayaan masyarakat. ${ }^{40}$ Pandangan ini sangat relevan dimana sebagian besar masyarakat Indonesia justru hidup di desa-desa. Kawasan desalah yang mensuplai pangan ke perkotaan. Jika kemudian pembangunan dan pemberdayaan desa berhenti, maka tentunya kota juga akan kehilangan daya dukung untuk terus berkembang.

Pesantren tumbuh dan berkembang dalam alam pedesaaan. Sehingga kemudian keberadaan pesantren di pedesaan memberikan pengaruh yang signifikan terhadap pengembangan masyarakat. Tidak saja dalam bentuk faham keagamaan tetapi juga sampai pada pola hidup dan keterampilan masyarakat. ${ }^{41}$ Walaupun dikenal dengan tradisionalisme tetapi pesantren menjadi titik pencerahan masyarakat. Dengan aktivitas yang berpusat pada pendidikan kemudian pesantren memberikan pencerahan dalam pola pikir yang kemudian diistilahkan dengan pembaruan pola pikir. Ini kemudian berakibat pada peningkatan sumber daya manusia. Dengan demikian sebagai basis budaya di pedeesaan, maka pesantren menjadi motor penggerak dalam kualitas sumber daya manusia. Ini tentunya akan menjadi penggerak sekaligus agen perubahan di masyarakat.42 Pesantren memberikan penguatan keterampilan dalam bentuk pendidikan kejuruan. Walaupun masih terbatas dalam keterampilan pramuka, koperasi dan peternakan. Dengan mengelola koperasi secara bergiliran, maka santri memperoleh kemampuan untuk mengelola perusahaan untuk kepentingan ekonomi. Dengan demikian secara langsung mereka melakukan praktik akan memberikan pengalaman belajar sekaligus keterampilan dari tangan pertama untuk memupuk minta dan tanggung jawab dalam menjalankan kegiatan bisnis. 43

Perkembangan iptek di luar pesantren sangat cepat, untuk itu pesantren harus melakukan akselerasi terhadap pengembangan iptek tersebut. Dengan demikian pesantren berperan didalam melakukan adaptasi kebudayaan sesuai dengan ruh dan nilai masyarakat pesantren. Sosio kultural pesantren kemudian akan menjadi faktor penting dalam peningkatan SDM tersebut. ${ }^{44}$ Pesantren memiliki sifat yang multi dimensional. Bahkan memiliki daya tahan terhadap perubahan. Kecuali jika kemudian perubahan itu digagas oleh internal pesantren

\footnotetext{
40 Gunawan Sumodiningrat, Pemberdayaan Sosial: Kajian Ringkas Tentang Pembangunan Manusia Indonesia, (Jakarta: Penerbit Buku Kompas, 2007), hal. xv.

41 Abd. A'la, Pembaruan Pesantren, (Yogyakarta: Pustaka Pesantren, 2006), hal. 1-2.

42 Rofiq. A, dkk., Pemberdayaan Pesantren, (Yogyakarta: Pustaka Pesantren, 2005), hal. xii-xiii.

43 M. Dawam Rahardjo, The Kiyai, The Pesantren, and The Village: A Preliminary Sketch, dalam Ahmad Ibrahim, et al., Reading on Islam in South East Asia, (Singapura: ISEAS, 1985), hal. 241.

${ }^{44}$ H. Sonhadji Sholeh, Konsep-konsep Pengembangan SDM, dalam A. Halim, dkk, Manajemen Pesantren, (Yogyakarta: Pustaka Pesantren, 2005), hal. 7.
} 
sendiri kemudian memunculkan pembaruan yang bersifat dinamis dan positif bagi kemajuan pesantren. ${ }^{45}$ Dalam perjalanan sejarah, pesantren memberikan kontribusi bagi pembangunan nasional di Indonesia.46 Dengan elemen pesantren memungkinkan keterlibatan yang tinggi dalam pembangunan. ${ }^{47}$ Florian Pohl memandang bahwa pesantren menjadi tempat bagi tersemainya nilai-nilai kemanusiaan dan keadilan sosial.48 Dengan demikian peran yang dimainkan pesantren ini bisa diperluas sampai kepada pemberdayaan untuk kehidupan. Dalam hal ini juga termasuk di dalamnya bagaimana pesantren memberikan pembekalan bai santri agar bisa mempunyai keterampilan dalam pengelolaan pertanian.

Dengan demikian, keberadaan pesantren yang berada di pedesaaan, akan menjadi satu peran yang memungkinkan jika mereka turut untuk memberdayakan lingkungan. Pesantren telah mengalami metamorfosis yang signifikan. ${ }^{49}$ Sesuai dengan keberadaan mereka masingmasing. Penyesuaian dengan lingkungan dan adaptasi menjadi nilai lebih pesantren bagi masyarakat. Dengan landasan inilah, maka satu penelitian yang berhubungan dengan pemberdayaan masyarakat melalui pertanian menjadi penting. Bagaimana pesantren mengelola potensi yang dimiliki untuk memberikan keterampilan bagi santri. Dimana selama ini pesantren identik dengan pendidikan agama semata-mata. Di sisi lain, pesantren mulai mengkreasikan potensi lokal sehingga bisa berperan lebih maksimal lagi.

\section{c. Pesantren Roudhatul Khuffadz, Sorong}

Pesantren Roudhatul Khuffadz terletak di Aimas, ibukota kabupaten Sorong. Pesantren ini mengelola pendidikan diniyah berlangsung sore (ba'da Ashar) dan juga berlanjut sampai malam (ba'da sholat isya). Pendidikan formal yang dijalankan masih sebatas madrasah ibtidaiyah dan pada tahun 2011 ini menamatkan untuk pertama kalinya. Adapun santri yang

45 Marzuki Wahid, Suwendi, Saefuddin Zuhri, Pesantren Masa Depan: Wacana Pemberdayaan dan Transformasi Pesantren, (Jakarta: Pustaka Hidayah, 1999), hal. 333.

46 Robert Kingham, The Impact Of Pesantren In Education And Community Development In Indonesia, proceedings from and [sic] international seminar by Technical University Berlin and Friederich [i.e. Friedrich]-Naumann-Stiftung in Berlin, July 9-13, 1987, hal. 69.

47 Abdullah Syukri Zarkasyi, Gontor \& Pembaharuan Pendidikan Pesantren, (Jakarta: RajaGrafindo Persada, 2005), hal. 4.

48 Florian Pohl, Interreligious Harmony and Peacebuilding in Indonesian Islamic Education, dalam Peace Psychology in Asia, Cristina Jayme Montiel \& Noraini N. Noor (eds), (Springer Science+Business Media, 2009), London, hal. 147.

${ }^{49}$ M. Amin Haedari, Transformasi Pesantren: Pengembangan Aspek Pendidikan, keagamaan, dan sosial, (Jakarta: LeKDiS, 2006) hal. 50. 
mukim di pesantren adalah dari berbagai daerah di Papua Barat. Selama mereka tinggal di asrama pesantren, mereka tetap mengikuti pendidikan formal di sekolah terdekat. Terutama pada tingkatan sekolah menengah. Adapaun pada tingkatan sekolah dasar, mereka mengikuti pendidikan di madrasah ibtidaiyah yang sudah ada dalam kawasan pondok pesantren.

Di sore hari, santri setelah pulang sekolah dan beristirahat, maka mereka mengikuti pengajian dalam bentuk halaqah yang diasuh oleh pimpinan pondok. Kemudian di malam hari mengikuti pengajian sesuai dengan kurikulum madrasah diniyah. Di hari libur sekolah kemudian santri dibagi sesuai dengan minat dan kemampuan masing-masing. Sebagaimana dikatakan Kiyai Yasin "santri akan dikelompokkan kepada beberapa kelompok disesuaikan dengan minat dan kemampuan masing-masing. Jika santri yang masih usia sekolah dasar, maka mereka bertugas untuk memberi makan hewan ternak. Tetapi untuk santri yang sudah menginjak sekolah menengah, maka mereka kemudian ditugaskan menjaga hewan ternak tersebut." 50

Di lingkungan pesantren tersedia berbagai lahan yang dikelola langsung oleh santri. Di area tersebut terdapat, peternakan ayam, sapi, bebek, di samping tanaman jangka pendek seperti cabe, tomat dan palawija. Di samping itu juga untuk menyuplai makanan ternak, terdapat tanaman rumput gajah. Kemudian juga dilaksanakan sistem tumpang sari bagi peternakan ayam, dengan menggandengkan dengan tambak ikan lele dan di sekitar masjid sebagai tempat pembuangan bekas air wudhu terdapat kolam ikan nila. Dengan memberikan kesempatan bagi santri untuk langsung belajar, maka kemudian akan mengasah keterampilan mereka yang tidak dimulai dengan teori. Sementara jika dalam proses praktik di lapangan terjadi kesalahan, maka akan diberikan penjelasan teoritis secara langsung. Demikian pula arahan dan petunjuk kiyai dan pimpinan pondok kemudian akan diberikan dalam waktuwaktu tertentu saja. Porsi untuk teori sangat sedikit. Dibandingkan dengan praktik langsung di lapangan ini sangat mendominasi proses pembelajaran. Untuk itu Kiyai yasin menjelaskan:

"Dengan memberikan kesempatan untuk berinteraksi dan mengalamai proses belajar, maka santri akan lebih banyak mengamati dan kemudian akan mengambil kesimpulan sendiri terhadap pengalaman yang berulang. Sebagai proses pendidikan, maka ini akan menjadi satu cara untuk tidak langsung memberikan arahan teoritis semata-mata, tapi belajar langsung dari pengalaman. Jika ini diterapkan, maka kemudian santri akan lebih

50 Wawancara dengan pengasuh pondok pesantren Roudhatul Khuffadz, pada tanggal 12 April 2011. 
menyimpan memori itu secara permanen dan lama. Dibandingkan dengan hanya ceramah semata-mata di ruang kelas." 51

Pertanian dan peternakan dipilih sebagai fokus pembelajaran, ini semata-mata memandang bahwa potensi alam yang ada di Papua didominasi oleh luasnya lahan pertanian yang belum tergarap. Demikian pula dengan pertanian maka tentu akan diperlukan ternak dalam mendampingi proses pertanian tersebut. Bekal yang diperoleh santri ketika berada di pesantren kemudian akan memberikan keterampilan yang tidak jauh dari masyarakat yang ditempatinya. Sehingga kemudian tidak menjadikan terasing dan justru jauh dari kebutuhan masyarakat. Pertanian dan peternakan menjadi satu kebutuhan penting di masyarakat Sorong dimana beberapa bahan pangan mesti diimpor dan didatangkan dari daerah lain. Dengan kemampuan mengelola lahan pertanian akan memberikan daya dukung bagi kemandirian masyarakat. Produksi pangan yang dihasilkan secara internal akan mudah bersaing dengan produk luar. Di samping itu, keterampilan ini hanya menjadi pelengkap dimana kemampuan keagamaan yang utama juga menjadi satu hal penting untuk diajarkan ke masyarakat. Minimal untuk kesalehan individual yang memungkinkan untuk diajarkan kepada keluarga.

Membimbing dalam kemampuan agama adalah yang utama. Adapun untuk keterampilan sebagai tambahan dan pengayaan. Jika mereka kembali ke masyarakat, maka bekal keterampilan ini menjadi alat komunikasi dan komplementer bagi kehidupan sehari-hari. Di samping itu alumni pesantren dituntut untuk menjadi tenaga bagi kegiatan keagamaan di masyarakat. Dimana muslim menjadi minoritas dan pemahaman agama yang sangat terbatas terutama bagi muallaf. Alumni pesantren pada gilirannya akan menjadi dai di lingkungan masing-masing. Hal ini, memberikan contoh bahwa seorang alumni pesantren tidak hanya mahir berada di mimbar tetapi yang paling penting adalah adanya keterampilan untuk mengelola potensi masyarakat. Dengan demikian wajah Islam yang damai akan dominan dibandingkan menjadi hanya insan yang bisa berdiskusi dan berwacana. Dengan demikian simpati dan keinginan untuk bersosiliasi dengan komunitas muslim akan terbuka.

Gambaran ini, menunjukkan bahwa alumni pesantren justru kemudian berjalan dan menempuh tugas sebagai khalifah di muka bumi. Tidak lagi menjadi beban bagi keluarga dan masyarakat tetapi justru menjadi pionir bagi pengembangan keluarga dan lingkungannya. Tidak sebatas umat Islam saja tetapi juga bagi lingkungan. Dimana keberadaan mereka tidak

51 Wawancara dengan Kiyai Yasin, 8 Maret 2011. 
dalam lingkungan muslim mayoritas. Tetapi juga tumbuh dan berkembang bersama dengan penganut agama lain. Dengan ilmu dan keterampilan yang ditekuni sejak dari pesantren kemudian akan memberikan daya dukung bagi proses kreatif di lingkungannya. Jika kemudian dengan jumlah puluhan yang ada, masing-masing tersebar di lingkungan yang berbeda, maka akan menjadi titik-titik bagi kelangsungan pemberdayaan masyarakat.

Pengalaman belajar yang didapatkan semasa di pesantren Roudhatul Khuffadz adalah upaya untuk memberikan kebebasan bagi setiap santri dalam mempelajari keterampilan yang berhubungan dengan peternakan dan pertanian sehari-hari. Kegiatan tambahan ini dalam rangka mengasah kemampuan mereka dalam bentuk keterampilan. Berikutnya ketika mereka sudah merdeka dan bebas dalam menentukan aktivitas, maka pada saat itu akan berkontribusi bagi dirinya. Di saat mereka mampu membangun diri sendiri, maka tentunya akan membantu masyarakat dalam melakukan pengembangan kapasitas.

\section{E. IMPLIKASI TEORITIS}

Pesantren telah memberikan upaya yang luas, tidak saja dalam bidang pendidikan, tetapi mulai memberikan penguatan dalam pemberdayaan di masyarakat. Keterampilan yang dilatihkan di pesantren tidak terbatas dalam bidang keagamaan. Tetapi juga sudah mulai merambah keterampilan dalam bidang pertanian. Studi dalam pesantren Roudhatul Khuffadz, memberikan bukti bahwa pesantren telah memberikan transformasi dalam berbagai kehidupan masyarakat luas. Ini sejalan dengan teori yang disampaikan Zubaidi Habibullah As'ary yang memberikan gambaran bahwa pesantren telah membuka diri. Keberadaan teknologi moderen, kemudian mulai bersentuhan dengan wacana globalisasi memunculkan dinamika dan transformasi yang pada gilirannya akan memberikan eksistensi tersendiri bagi lembaga pesantren ${ }^{52}$. Persentuhan dengan nilai modernitas merupakan perkembangan dinamis dalam pandangan Yasmadi53. Kemudian persentuhan dengan modernitas ini justru kemudian memperkuat keberadaan pesantren. Dengan transformasi seperti ini maka pergerakan ke depan pesantren akan semakin mengukuhkan keberadaannya di masyarakat.

Pesantren kemudian tidak hanya berada dalam wacana lingkungan, tetapi juga dengan kesadaran spiritual turut memberikan tempat bagi perlunya mengasah keterampilan untuk

52 Zubaidi Habibullah As'ary, Moralitas Pendidikan Pesantren, (Yogyakarta: PT. Kurnia Kalam Semesta, 1996), hal. 3.

53 Yasmadi, Modernisasi Pesantren, (Jakarta: Ciputat Press, 2005), hal. 3. 
mempengaruhi perilaku masyarakat ${ }^{54}$. Ini menunjukkan keberadaan pesantren sejak dulu tidak terlepas dari kesadaran lingkungan. Justru pengembangan pesantren dimulai dari pengamatan akan kondisi lingkungan. Sebab dengan perkembangan pesantren, maka kemudian akan melakukan sinergi dengan lingkungan sekitar. Bahkan pesantren menjadikan lingkungan sekitarnya sebagai masyarakat binaan atau juga menjadikan lingkungan dan masyarakat sekaligus sebagai mitra pengembangan pesantren.

Salah satu masalah utama pendidikan kita adalah tidak adanya relevansi antara pendidikan dengan dunia kerja. Sehingga membuat lulusan pendidikan formal kemudian tidak mendapatkan tempat yang layak di dalam persaingan dunia kerja yang mengandalkan keterampilan. Dalam bahasa Azyumardi Azra bahwa pendidikan tidak dapat merespon dan dan mengantisipasi kebutuhan masyarakat dalam hal pekerjaan ${ }^{55}$. Tidak terdapat upaya kreatif bagi lembaga pendidikan untuk menjembatani kesenjangan tersebut. Justru dengan adanya temuan dalam makalah ini yang mendapati bahwa pesantren Roudhatul Khuffadz justru kemudian mengasah keterampilan santri untuk bertani membuktikan bahwa generalisasi ketidakmampuan lembaga pendidikan memberikan muatan kurikulum dalam mengantisipasi dunia kerja tidak terbukti secara penuh. Keberadaan pesantren ini, justru secara aktif membekali santri untuk dapat menjadi wirausaha di bidang pertanian. Secara luas, maka alumni pesantren dapat mengembangkan diri terhadap pola pertanian moderen. Ini dimungkinkan sebab area papua yang masih belum banyak digarap akan memberikan nilai tersendiri bagi santri ketika pada saatnya harus terjun ke masyarakat.

Konteks pesantren Roudhatul Khuffadz memberikan makna bahwa dalam proses pendidikan terjadi transfer dalam beberapa hal yaitu ilmu, nilai dan keterampilan. Pendidikan yang memberdayakan adalah pendidikan yang kemudian tidak hanya memberikan pengetahuan dalam bentuk kognitif tetapi lebih jauh dari itu adanya keterampilan yang bisa menjadi alat untuk menggambarkan pengetahuan yang diperoleh. Hasil penelitian ini kemudian sejalan dengan teori yang dikemukakan Haidar Putra Daulay bahwa proses pendidikan tidak bisa dibagi hanya dalam bentuk formal semata-mata ${ }^{56}$. Pendidikan juga bisa berarti proses pemahaman. Oleh karenanya jika kemudian penanaman nilai-nilai yang

\footnotetext{
54 Syamsul Arifin, Spiritualisasi Islam dan Peradaban Masa Depan, (Yogyakarta: Sipres, 1996), hal. 178.

${ }^{55}$ Azyumardi Azra, Paradigm baru Pendidikan Nasional, (Jakarta: Penerbit Buku Kompas, 2002), hal. xvii.

${ }^{56}$ Haidar Putra Daulay, Sejarah Pertumbuhan dan Pembaruan Pendidikan Islam di Indonesia, (Jakarta: Prenada Media Group, 2007), hal. 13-14.
} 
kemudian wujud dalam bentuk keterampilan, maka sesungguhnya itu juga dapat disebut dengan inti pendidikan itu sendiri. Hanya saja bentuknya tidak dalam bentuk formal dan berlangsung dalam ruangan pembelajaran. Justru proses seperti ini kemudian akan lebih bermakna dan memberikan pemahaman yang paripurna bagi para santri.

\section{F. PENUTUP}

Dari beberapa uraian di atas dapat disimpulkan bahwa dalam menghadapi krisis pendidikan Islam bukan hanya sekedar wacana saja, akan tetapi bisa mewujudkan sehingga krisis yang dihadapi pendidikan Islam bisa terselesaikan. Pemisah antara pendidikan Islam dengan pendidikan umum dalam konfigurasi pendidikan nasional dapat diatasi. Pendidikan Islam menjadi katalisator dan menjawab kritik berbagai kalangan bahwa pesantren menjadi bibit bagi tersemainya aksi kekerasan.

Tujuan dan fungsi pendidikan Islam, metode, materi (kurikulum) harus dikoreksi dan revisi secara berani dan membenahi keorganisasiannya (kelembagaan). Dengan demikian, pendidikan Islam akan kembali pada posisi yang sebenarnya dalam memberdayakan umat Islam di Indonesia yang sedang menuju pada masyarakat industrial dengan berbagai tantangan etos kerja, profesionalisme, dan moralitas. Sekaligus mampu memisahkan wacana-wacana tentang pendidikan dikotomi khususnya di lembaga pendidikan Islam, sehingga dengan tersebut tidak ada pendidikan Islam dan pendidikan umum semuanya adalah sama.

Dengan melihat implementasi yang dijalankan pesantren Roudhatul Khuffadz menunjukkan bahwa walaupun berada dalam lingkungan yang mayoritas muslim tetapi pesantren memberikan satu hal yang bisa dijadikan bukti bahwa dengan kesadaran minoritas menjadikan pesantren tetap berkiprah. Justru dengan minoritas tersebut, identitas muslim kemudian lebih kuat dan kemudian menjadi daya dukung untuk turut memberikan sumbangan bagi kemajuan pendidikan lokal. 


\section{DAFTAR PUSTAKA}

A, Rofiq., dkk., Pemberdayaan Pesantren, (Yogyakarta: Pustaka Pesantren, 2005).

A'la' Abd., Pembaruan Pesantren, (Yogyakarta: Pustaka Pesantren, 2006).

Aly, Hery Noer dan S, Munzier, Watak Pendidikan Islam, (Jakarta Utara: Friska Agung Insani, 2003).

Arif, Ahmad dan Aulia, Luki; Sitaung Frederick, Guru Sejati di Papua, Kompas, Sabtu, 1 September 2007.

Arifin, Anwar, Format Baru Pengelolaan Pendidikan, (Jakarta: Pustaka Indonesia, 2006).

Arifin, M, Kapita Selekta Pendidikan, (Jakarta: Bina Aksara, 1991).

Arifin, Syamsul, Spiritualisasi Islam dan Peradaban Masa Depan, (Yogyakarta: Sipres, 1996).

As'ary, Zubaidi Habibullah, Moralitas Pendidikan Pesantren, (Yogyakarta: PT. Kurnia Kalam Semesta, 1996).

Asmani, Jamal Ma'ruf, Manajemen Pengelolaan dan Kepemimpinan Pendidikan Profesional: Panduan Quality Control bagi Para Pelaku Lembaga Pendidikan, (Yogyakarta: Diva Press, 2009). 
Aspinall, E. dan Berger, M. T., The Break Up of Indonesia? Nationalism after Decolonisation and the Limits of the Nation-State in Post-Cold War Southeast Asia, Third World Quarterly, 22 (6), 2001.

Azra, Azyumardi, Paradigma baru Pendidikan Nasional, (Jakarta: Penerbit Buku Kompas, 2002).

Azra, Azyumardi, Wacana Tentang Minoritas Muslim, Kata Pengantar dalam M. Ali Kettani, Minoritas Muslim di Dunia Dewasa Ini, (Jakarta: Rajawali Pers, 2005).

Budisantoso, Suryosumarto, Ketahanan Nasional Indonesia, Penangkal Disintegrasi Bangsa dan Negara, (Jakarta: Pustaka Sinar Harapan, 2001).

Daulay, Haidar Putra, Sejarah Pertumbuhan dan Pembaruan Pendidikan Islam di Indonesia, (Jakarta: Prenada Media Group, 2007).

Fadjar, A. Malik, Holistika Pemikiran Pendidikan, (Jakarta: PT RajaGrafindo Persada, 2005).

Greg Barton, Gagasan Islam Liberal di Indonesia, Pemikiran Neo-Modernisme Nurcholish Madjid, Djohan Efendi, Ahmad Wahib, dan Abdurrahman Wahid, 1968-1980, terj. Nanang Tahqiq, (Jakarta: Paramadina, 1999).

Haedari, M. Amin, Transformasi Pesantren: Pengembangan Aspek Pendidikan, keagamaan, dan sosial, (Jakarta: LeKDiS, 2006).

Hasbullah, Kapita Selekta Pendidikan Islam, (Jakarta: PT. Grafindo Perkasa, 1996).

Kartasasmita, Ginandjar, Pembangunan Untuk Rakyat: Memadukan Pertumbuhan dan Pemerataan, (Jakarta: Center for Information and Development Studies, CIDES, 1996).

Kingham, Robert, The Impact Of Pesantren In Education And Community Development In Indonesia, proceedings from and [sic] international seminar by Technical University Berlin and Friederich [i.e. Friedrich]-Naumann-Stiftung in Berlin, July 9-13, 1987.

M. Suyudi, Pendidikan dalam Perspektif al-Qur'an Integrasi Epistemologi Bayani, Burhani, dan Irfani, (Yogyakarta: Mikraj, 2005).

Makdisi, George, Terjemahan A. Syafii Maarif, 1996.

Man, W. K. Che, Muslim Separatism, (Oxford: Oxford University Press, 1990).

Mas'ud, Abdurrahman, Menggagas Format Pendidikan Nondikotomik: Humanisme Religius sebagai Paradigma Pendidikan Islam, (Yogyakarta: Gama Media, 2002).

Mastuhu, Dinamika Pendidikan Pesantren: Suatu Kajian tentang Unsur dan Nilai Sistem Pendidikan Pesantren, Seri INIS XX, (Jakarta: INIS, 1994).

Muchtar, Hifni, Fakta dan Cita-Cita Sistem Pendidikan Islam di Indonesia, (Yogyakarta: UNUSIA No.12 Th.XIII. UII.1992).

Muhaimin, Pengembangan Kurikulum Pendidikan Agama Islam: di Sekolah, Madrasah, dan Perguruan Tinggi, (Jakarta: PT RajaGrafindo Persada, 2005).

Mujahidah, Analisis Terhadap Interaksi Sosial Antar Pemeluk Agama dan Etnis di Kota Sorong, (Sorong: Pustaka Rafana, 2010).

Nata, Abudien, Tokoh-tokoh Pembaharuan Pendidikan Islam di Indonesia, (Jakarta: PT Raja Grafindo Persada, 2005).

Panitia Penyusunan Riwayat Hidup dan Perjuangan K.H. Imam Zarkasyi, Biografi K.H. Imam Zarkasyi: Dari Gontor Merintis Pondok Modern, (Ponorogo: Gontor Press, 1996).

Partanto, Pius A, dkk, Kamus Ilmiah Populer, (Surabaya: Arkola, 1994). 
Pohl, Florian, Interreligious Harmony and Peacebuilding in Indonesian Islamic Education, dalam Peace Psychology in Asia, Cristina Jayme Montiel \& Noraini N. Noor (eds), (Springer Science+Business Media, 2009), London.

Priatna, Tedi, Reaktualisasi Paradigma Pendidikan Islam: Ikhtiar Mewujudkan Pendidikan Bernilai Ilahiah dan Insaniah di Indonesia, (Bandung: Pustaka Bani Quraisy, 2004).

Qomar, Mujamil, Pesantren; dari Transformasi Metodologi Menuju Demokratisasi Institusi, (Jakarta: Erlangga, $\mathrm{tt}$ ).

Rahardjo, M. Dawam, The Kiyai, The Pesantren, and The Village: A Preliminary Sketch, dalam Ahmad Ibrahim, et al., Reading on Islam in South East Asia, (Singapura: ISEAS, 1985).

Rodinson, Maxime, The Notion of Minority in Islam, dalam Gerard Chaliand (ed.), Minority Peoples in the Age of Nation-States, (London: Pluto Press, 1989).

Rose, M. Arnold dan Rose, B. Caroline, Minority Problems, (New York: Harper and Row, 1972).

Rozi, Syafuan, Nasionalisme, Demokratisasi, dan Sentimen Primordialisme di Indonesia: Problematika Identitas Keetnisan versus Keindonesiaan pada Studi kasus Aceh, Papua, Bali, dan Riau, Jurnal Penelitian Politik, 6 (1), 2009.

Sajogyo, Memahami dan Menanggulangi Kemiskinan di Indonesia, (Jakarta: Gramedia Widiasarana Indonesia, 1996).

Sholeh H. Sonhadji, Konsep-konsep Pengembangan SDM, dalam A. Halim, dkk, Manajemen Pesantren, (Yogyakarta: Pustaka Pesantren, 2005).

Sofyan, Muhammad, Agama dan kekerasan dalam Bingkai Reformasi, (Yogyakarta: Penerbit Media Pressindo, 1999).

Sumodiningrat Gunawan, Pemberdayaan Sosial: Kajian Ringkas Tentang Pembangunan Manusia Indonesia, (Jakarta: Penerbit Buku Kompas, 2007).

Suroyo, Berbagai Persoalan Pendidikan Nasional dan Pendidikan Islam di Indonesia, Jurnal Ilmu Pendidikan Islam, Problem dan Prospeknya, (Yogyakarta: Volume 1, Fak. Tarbiyah IAIN Sunan Kalijaga, 1991).

Suwito, Sosiolinguistik: Teori dan Problema, (Surakarta: Henary Offset, 1982).

Suyata, Penataan Kembali Pendidikan Islam pada Era Kemajuan Ilmu dan Teknologi, (Yogyakarta: UNISIA, No. 12 th.XIII, UII, 1992).

Tilaar, H.A., Sistem Pendidikan Nasional yang Kondusif bagi Pembangunan Masyarakat Industri Modern Berdasarkan Pancasila, Makalah Utama Kongres Ilmu Pengetahuan Nasional V.

Usa, Muslih, Pendidikan Islam di Indonesia: Antara Cita dan Fakta (Suatu Pengantar), (Yogyakarta: Tiara Wacana, 1991).

Wahid, Marzuki; Suwendi; Zuhri, Saefuddin, Pesantren Masa Depan: Wacana Pemberdayaan dan Transformasi Pesantren, (Jakarta: Pustaka Hidayah, 1999).

Yasmadi, Modernisasi Pesantren, (Jakarta: Ciputat Press, 2005).

Zarkasyi, Abdullah Syukri, Gontor E Pembaharuan Pendidikan Pesantren, (Jakarta: RajaGrafindo Persada, 2005). 